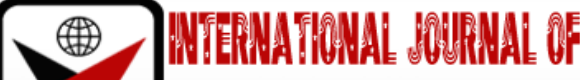

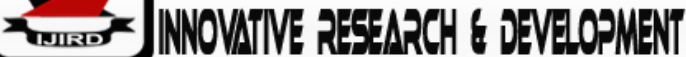

ISSN 2278-0211 (Online)

\section{The Trends and Management of the Industrial Attachment at the Tamale Technical University, Ghana}

\author{
Imoro Bashiru \\ Officer, Department of Industrial Liaison Office, Tamale Technical University, Ghana \\ Mohammed Mansur Hussein \\ Student, Department of Art Education, University of Education, Winneba, Ghana
}

\begin{abstract}
:
Academic attachment is increasingly becoming an integral part of training methodology across the various careerbased training institutions today. This practice can be observed from the Educational and Health to the Technical and Vocational Tertiary Institutions. The Ghana's Educational Act 745 of 2007 is to provide opportunities for skills development, which is one of the main objectives of the polytechnics and technical universities in Ghana. Thus, there is need for the industrial attachment as part of the core methodology of training students at the Polytechnics and the Technical Universities. This is realized by the harmonious coordination of the Training institution with the related industry for the said objective to be achieved. Of all the training methods used at the technical universities and polytechnics, Industrial Attachment (IA) is found to be the key to professional etiquette that accords the student the opportunity to marry the classroom theory with the reality at the working field. The paper reviews the historical background of industrial attachment, its relevance in the training process, the role of University and the other stake holders in industrial attachment (IA) and the general benefits of industrial attachment to the stakeholders. The paper also stressed on the challenges the industrial attachment programme is facing, and spelt out some recommendations for the success of the programme at the Tamale Technical University (TaTU). The review will guide the industrial attachment stake holders improve upon the industrial attachment status at the Tamale Technical University and beyond in enhancing multiple benefits and minimize the challenges.
\end{abstract}

Keywords: Industrial attachment, tamale technical university, liaison office, polytechnic and attaché

\section{Introduction}

Tamale Technical University (TaTU), began as a Trades Training Centre (TTC) in 1951 and become the Government Training School in 1954 and in 1960, it was converted to a Junior Technical Institute. The school was elevated to the status of a Polytechnic on August 23, 1992. As part of the Educational Reform Programme and coupled with the enactment of the PNDC Law 321 in 1992, the status of the institute was raised to a Polytechnic together with Accra, Kumasi, Ho, Cape Coast and Takoradi Polytechnics (Government of Ghana, 1992; Tamale Polytechnic, 2012). With the passing of the Technical University Act, 2014 by the Parliament of Ghana and accented by the President, the institution after satisfying the requirements specified in the Act, was upgraded to a Technical University in 2016. The University currently trains students up to Bachelor of Technology level with provisions to mount higher degree Programmes in the future (Tamale Technical University, 2018).

One of the main objectives of the technical university under Act 745 of 2007 is to provide opportunities for skills development (Amankwa, 2011). To achieve this objective, the institutions of Technical and Vocational education adopted experiential learning technique which according to Adjei et al (2014) is the most efficient learning approaches employed in delivering effective technical and vocational education and training. Thus, Industrial Attachment (IA) became a compulsory 4- credit hour programme for all Level 100 Student of Diploma in Technology, Level 100 and 200 HND students and all the Level 100 to 300 BTEC students. Skills development is best attained when the student is given an opportunity for a hands-on training through Industrial Attachment (Tamale Technical University, 2018). Thus, it is important for the University to pay serious attention to this component of the curriculum in order to produce graduates acceptable to industry in the name of maintaining standards as a Technical University.

Industrial attachment at the polytechnics and the Technical Universities is generally coordinated and supervised under the mandate of the Liaison department. It involves the systematic placement of trainees in industry where they can be helped to acquire specific skills and competences relating to their area of study. It requires proper planning and effective supervision to achieve targeted results. The students are expected to sharpen their skills in the use of modern facilities and processes for work readiness. The attachment programme is categorized in several forms - Viz; General attachment for all students and members of staff; Internship for Bachelor of Technology (B. Tech.) students; Competency - 
based Training (CBT) programme for Engineering students; Semester -out programme for Fashion students; Industrial and Educational visits for staff and students (Nduro, 2015; Tamale Technical University, 2018; Adjei et al, 2014).

\section{Historical Precedence}

Elevated to the status of a Polytechnic on August 23, 1992, there were only few students. As such, the organization of Industrial Attachment was not a problem. However, with an increase in students' enrolment, Industrial Attachment became a big problem (Imoro \& Acortsu 2015). Before the year 2006, the Institution engaged students in industrial tours and students were asked to write reports which were marked (Nduro, 2015; Imoro \& Acortsu 2015; Tamale Technical University, 2018; Adjei et al, 2014).

Imoro \& Acortsu (2015) indicated that on the 30th November 2004, there was a meeting for all Liaison Officers at the Civil Servants Association auditorium in Accra. The purpose of the meeting was to discuss a Draft report on the Strategic Plan for Industrial Attachment Project. We were informed that, the National Board for Professional and Technical Examination (NABPTEX) had taken an oversight responsibility of Industrial Attachment (Imoro \& Acortsu, 2015; Adjei et al, 2014). The then Executive Secretary, promised to organize a special training programme for all Liaison Officers but that promise never materialized (Imoro \& Acortsu, 2015; Nduro, 2015; Tamale Technical University, 2018).

A National Industrial Attachment Committee was formed and we were informed that a bill on Industrial Attachment was placed before Parliament, but nothing was heard ever since. In the words of the French Philosopher, Rousseau it was like 'sending wise men to the top of a mountain to show them a promised land which was to be denied them'. It was like a dream that has gone with the wind (Imoro \& Acortsu, 2015; Tamale Technical University, 2018).

During the period 16th-18th April 2008, the Management of Takoradi Polytechnic sponsored a capacity -building workshop for all Liaison Officers at Kumasi Polytechnic. Dr. Apori was one of the resource persons. At the same period, NABPTEX also organized a Competency - Based Assessment Workshop for all Rectors and Liaison Officers of the Polytechnics at Dodowa which also fell within the same period $-16^{\text {th }}$ to $18^{\text {th }}$ April 2008 (Imoro \& Acortsu, 2015; Tamale Technical University, 2018).

In 2009, an Assistant Industrial Liaison Officer was appointed. His appointment took effect from 1st April 2009. The Assistant Liaison Officer together with the Liaison Officer paid a working visit to Kumasi, Accra and Takoradi Polytechnics to share ideas and experiences with their counterparts (Imoro \& Acortsu, 2015; Tamale Technical University, 2018).

From the 1st to 3rd March 2010, a three-day workshop was organized for all Vice Rectors and Liaison Officers at Takoradi Polytechnic on the theme 'Practical Industrial Training in Polytechnic Education, the way forward'. The then Vice Rector of Tamale Polytechnic could not attend due to an equally important engagement elsewhere (Imoro \& Acortsu, 2015; Tamale Technical University, 2018).

On the $9^{\text {th }}$ of April 2010, there was a workshop for both staff and students' representatives of Tamale Polytechnic at the Distance Education Learning Centre on Industrial Attachment. The resource persons were Rev. Professor D.K. Nyakoh and Mr. Norbert Adjei, the Liaison Officer, all from Takoradi Polytechnic (Imoro \& Acortsu, 2015; Tamale Technical University, 2018).

Activities within the Industrial Liaison unit of Tamale Technical University continue to progress steadily up to date even though it continuous to be saddled by the day-to-day challenges associated with most organizations and departments (Imoro \& Acortsu, 2015; Tamale Technical University, 2018).

\section{The Relevance of Industrial Attachment}

The competitive and competent production of the nation's human resource especially, the career and technical based area depends directly on the Polytechnics and the Technical Universities (Imoro \& Acortsu, 2015; Tamale Technical University, 2018). Thus, it is mandatory for the university and the related industries of concern to examine its relevance for the realization of the ultimate career developmental mission. Below was some core relevance of internship identified by Imoro \& Acortsu (2015);

- It is required by law as part of the training scheme in Polytechnics/Technical Universities in Ghana;

- Learning by students is enhanced by their exposure to modern technology;

- Both staff and students stay abreast with current trends in industry;

- Confidence level of the students and staff is increased as theory is complemented by practical;

- Institution/industry linkage is greatly enhanced;

- Reconciliation of theories learnt by students in the class room with practical approaches in industry;

- Develop a relationship with a mentor and cultivate a vast network of contacts.

\section{The Roles and Responsibility of University and the Other Stake Holders in Industrial Attachment (IA)}

The management of the industrial attachment programme is under the mandate of the Industrial Liaison department (Imoro \& Acortsu, 2015; Tamale Technical University, 2018). Imoro \& Acortsu, (2015) added that, the industrial attachment unit is under the office of the Pro Vice Chancellor of the University. It is responsible for overseeing the day to day running of industrial attachment and related matters from scouting of industries or firms for attachment to the supervision and reporting on successes of the said attachment (Tamale Technical University, 2018). The office of the Liaison department is also responsible for linking the University with the related industries and firms in the name of harmonizing the institutional and industrial goals (Dondofema et al, 2020; Imoro \& Acortsu, 2015; Tamale Technical University, 2018). This will enhance effective coordination between the respective stakeholders of the educational and 
training programme, which will go a long way to prevent the mismatch between the University and industry (Dondofema et al, 2020; Tamale Technical University, 2018; Nduro et al. 2014, The Agricultural of Kenya, 2014).

On the bases of the role of the University in the attachment programme, the university sensitizes partner organizations on the importance of industrial Attachment and the need to mentor and provide adequate supervision for the attaché (Imoro \& Acortsu, 2015). The provision of an enabling environment for students and staff members of the Technical University to engage in Industrial Attachment is the University's role (Tamale Technical University, 2018; Imoro \& Acortsu, 2015). Playing a supervisory responsibility of students and staff on Industrial Attachment, the university rolls out strategies for effective monitoring and evaluation of the I A programme. The university organizes orientation for students to fit into host industry and society at large. The university uses the feedback from the industries to review its course structure to suit the needs of industry, and initiate and formulate policies for Industrial Attachment programme and oversee their implementation (Imoro \& Acortsu, 2015; Dondofema et al, 2020).

With regard to the student (attachés) role in the I A, the student needs to be abreast with the industrial attachment policy requirements of the Technical University, as well as familiarize themselves with the rules and regulations of the host organization for a successful IA (Imoro \& Acortsu, 2015). Students also need to write a comprehensive report to the Technical University about the experiences gained, challenges as well as the way forward to improve the programme subsequently (Imoro \& Acortsu, 2015; Dondofema et al, 2020). During the I A, students need to conduct themselves professionally and avail themselves for supervision by the host organization as well as an internal monitor from the Technical University. This will guide them to learn and acquire the desired knowledge and skills related to their area of specialization (Tamale Technical University, 2018).

In the case of the Host Organization or Industry, they are expected to expose students to relevant activities and training opportunities. They also supervise and assess the progress of the student and collaborate with the university in this regard (Imoro \& Acortsu, 2015). The host organization or industry also suggest possible update to the curriculum of the Technical University to suit its needs and requirements so as to prevent mismatch between the training institutions and the industries. The Industry may also be requested to release students back to the Technical University under special circumstances (Dondofema et al, 2020; Imoro \& Acortsu, 2015; Tamale Polytechnic, 2018).

According Imoro \& Acortsu (2015), another significant party is the Industrial Relations Committee (IRC). The Statutes of the Technical University stipulate that the Academic Board shall constitute a Sub- committee known as the Industrial Relations Committee to oversee the activities of Industrial Attachment and other related matters. Included as members of these committee are; The Pro Vice Chancellor as the Chairman, Dean of Students Affairs, Head of the Industrial Liaison Office, Two representatives from the Academic Board, An elected representative from the SRC and the Assistant Registrar or Assistant Industrial Liaison Officer as a Secretary (Imoro \& Acortsu, 2015; Tamale Technical University, 2018).

They added that, the said committee's main function is to oversee the industrial attachment programme as well as formulate policies and programmes to improve the organization of industrial attachment. They also ensure effective industrial collaboration with respective stakeholders of industrial attachment (Imoro \& Acortsu, 2015). During supervision, the committee avail themselves for the supervision of students on industrial attachment, since supervision is the heart of the attachment programme (Tamale Technical University, 2018).

\section{General Benefits of Industrial Attachment}

The benefits of the academic activity cannot be limited to only the students under attachment but extended to all stakeholders. As regards the host organization or industry's benefits. It serves as source of additional manpower to the organization. Attaché comes with trending initiatives from the Technical University. It serves as an avenue for the selection of competent potential employees by industry. Platform for grooming potential employees towards the achievement of the mandate of the industries. The programme serves as feedback from the Technical University to industry to enhance performance in increasing productivity (Imoro \& Acortsu, 2015; Dondofema et al, 2020; Tamale Polytechnic, 2018; Nduro et al. 2014, The Agricultural of Kenya, 2014).

In the case of the attachés benefits, exposure to the world of work is paramount in guiding the attaché to acquire practical experience in relation to the field of study. The programme also serves as platform for students' career information (Imoro \& Acortsu, 2015). Positive work attitude of students is enhanced, since the attaches is getting acquainted with work field etiquette. It also serves as avenue to developing a professional network as attaché is acquainted with people of the same profession (Imoro \& Acortsu, 2015; Dondofema et al, 2020; Tamale Polytechnic, 2018; Nduro et al. 2014, The Agricultural of Kenya, 2014).

For the benefits relating to the technical university, the attachment programme provides feedback from industry that strengthen academic curriculum to meet the industrial manpower needs. The attachment programme also complied with the statutory requirements for Technical Universities (Imoro \& Acortsu, 2015). Enhancing practical learning and knowledge acquisition for both students and Lecturers, the attachment programme bridges the gap of technological skills and knowledge between academic and practical skills. The collaboration between industry and academia is fostered through the industrial attachment programme (Imoro \& Acortsu, 2015; Tamale Polytechnic, 2018; Nduro et al. 2014, The Agricultural of Kenya, 2014).

\section{Challenges of the Industrial Attachment}

Currently, the organization of the Industrial Attachment has been action-packed, hectic and challenging (Nkrumah. et al, 2011). However, with the good will, practical assistance, encouragement and moral support from Management, the situation so far is much better (Nkrumah. et al, 2011; Tamale Polytechnic, 2014; Nduro et al. 2014). 
In the year 2015, an Industrial relations Committee meeting was organized in February in which the urgent need for getting permanent partnership with Industry and a policy document to stream line the activities of Industrial attachment featured prominently.

In March 2015, permission was granted for3 days to visit Organizations and Institutions within Tamale and environs. After the first day of visit, the mission was aborted because; the Liaison Officer who had travelled and returned insisted the Assistant Quality Assurance Manager who was part of the team for the placement finding was not supposed to be part. After approval was subsequently granted for the Liaison Officer to join the trip, the vehicle allocated to us was given out and all efforts to get it subsequently failed (Nkrumah. et al, 2011; Imoro \& Acortsu, 2015; Tamale Technical University, 2018; Nduro et al. 2014).

For several years, the Liaison unit partakes and monitors the Supervision of students until the year 2015 (Imoro \& Acortsu, 2015). From the year 2015until today, the Liaison unit could not partake in the Supervision of students due to lack of funds. Below are some pertinent challenges associated with the industrial attachment of the Tamale Technical University outlined by Imoro \& Acortsu, (2015);

- Poor planning of the programme

- Ineffective supervision

- Poor funding- no established training fund to augment and facilitate the training programme

- Lack of cooperation from industry

- Lack of incentives for trainers and trainees

- Poor perception of the programme

- Difficulty in finding placement for students

- Competition from sister training institutions

- Most often the travel allowances for supervisors are not adequate.

\section{Recommendations}

Polytechnics and the Technical Universities are career-focused tertiary intuitions. Emphasis should therefore be placed on skills acquisition by students. Thus, The Industrial Liaison unit of Tamale Technical University undoubtedly requires a serious refocusing and resourcing if it must be seen as playing the crucial role of effectively serving as a link between the University and Industry (Imoro \& Acortsu, 2015).All efforts should be channeled towards implementing the provisions of the Industrial Attachment policy document which will help streamline the activities of the unit on one hand and the management of Industrial attachment on the other hand (Imoro \& Acortsu, 2015; Tamale Technical University, 2018).

The unit urgently requires resourcing such as transport, giant photocopier and printers. Due to the large volume of photocopies that are made for students Industrial Attachment forms, a giant photocopier will undoubtedly help to reduce the stress the unit goes through to run copies (Imoro \& Acortsu, 2015).

To help improve the industrial Attachment (IA) programme, Imoro \& Acortsu (2015), suggested the following key recommendations outlined below;

- Priority attention must be given to industrial training for both staff and students.

- Staff and students involved must be insured.

- Adequate incentives must be given to staff who supervise and industries that accept the students.

- Students who fail to undertake industrial training should not be allowed to graduate

- A separate account should be opened for the Industrial Attachment unit to facilitate its work.

- A vehicle should be allocated to the unit to facilitate its work.

In addition to the above recommendation, the management parties (Tertiary Institutions) should generate or review the existing policies that govern the affairs of the industrial attachment programme, as well as, securing adequate funding, training mentors and supervises, creating effective monitoring and evaluation systems and defining appropriate timing for the programme.

\section{Conclusions}

From the review, it is clear that the industrial attachment programmes at the Technical University form the bases of students' exposure to the world of work. Different training strategies can be adopted along with the attachment for the desired results. There was an indication of mutual benefits for all stake holders involved in the attachment programme. The challenges of the industrial attachment facing all stakeholders towards the success of the programme is aloud and must be addressed for its successful implementation. Some of the efficient and effective strategies for improving the programme that was suggested were that, the management parties had to generate and review the existing policies that govern the affairs of the industrial attachment, as well as, securing adequate funding, training mentors and supervises, creating effective monitoring and evaluation systems and defining appropriate timing for the programme. The programme is considered inevitable in the environs of the Technical Universities and most tertiary institutions in Ghana. However, the role of the host Organization in relation to the level of the achievement of the programme objectives need to be reviewed.

\section{References}

i. $\quad$ Adjei, N. A. K., Nyarko, D. A., \& Nunfam, V. F. (2014). Perceptions of Stakeholders on the Industrial Attachment Programme of Ghanaian Public Polytechnics. 5(16), 134-144. Journal of Education and Practice. 
ii. Dondofema, J., Mwenje, J., \& Musemwa, L. (2020). The Industrial Attachment Programme - History, Benefits, Challenges and its Adoption in Zimbabwe: A Review 2. History of the Industrial Attachment Programme (IAP). 6(3), 412-420. Asian Journal of Education and Traininghttps://doi.org/10.20448/journal.522.2020.63.412.420

iii. Nduro, K., Anderson, I. K., Peprah, J. A., \& Twenefour, F. B. K. (2015). Industrial Training Programmes of Polytechnics in Ghana: The Pertinent Issues. 5(1). World Journal of Education; https://doi.org/10.5430/wje.v5n1p102

iv. Nkrumah, M. A., Apori, S. O., \& Adjei, N. A. K. (2011). Student industrial attachment programmme in Ghanaian Polytechnics: Challenges and Prospects. Tertiary Education Series, 4(3), 2-9.

v. Tamale Polytechnic (2012). Strategic plan: 2012-2016. Tamale: Tamale Polytechnic.

vi. Tamale Technical University (2018). Industrial Attachment Policy: Tamale: Tamale Technical University

vii. Choy, S., \& Haukka, S. (2009). Industrial Attachments for Instructors in TVET Delivery. 1367-1368. https://doi.org/10.1007/978-1-4020-5281-1

viii. Adjei, N. A. K., Nyarko, D. A., \& Nunfam, V. F (2020). Industrial Attachment in Polytechnic Education: An Approach to Polytechnic-Industry Nexus in Human Capital Development of Selected Polytechnics in Ghana. 5(33), 33-50.

ix. Khumalo, N. B. (n.d.). The value of industrial attachment to the archives and records management students at the National University of Science and Technology in Zimbabwe. 123-147.

x. Imoro, B. \&Acortsu W. (2015), Unpublished Report on the industrial attachment of an HND program in Tamale Polytechnic. December.

xi. Yawson, G.E., Ayiah-Mensah, A., Quayson, K., Adjorlolo A., Morrison, I. (2013). Unpublished Report on an industrial survey for the development of an HND program in Chemical Process technology at Takoradi Polytechnic. June.

xii. Matamande, W., Nyikahadzoi, L. Taderera, E. \& Mandimika, E.(n.d.). An investigation of the effectiveness of workrelated learning: A case of the industrial attachment program offered by the faculty of commerce, University of Zimbabwe. Journal of Instructional Pedagogies 1-10.

xiii. Amankwah, E. (2011). Relevance of competency-based training in polytechnic education for national development. Journal of Education and Practice. Volume 2, No.7, 2011

xiv. The Agricultural Society of Kenya (2014), Industrial Attachment / Internship Policy; Nairobi, June 